\title{
Response of Chinese cabbage grown in the spring season to differentiated forms of nitrogen fertilisation
}

\author{
Jan Krężel, Eugeniusz Kolota \\ Department of Horticulture \\ Wrocław University of Environmental and Life Sciences \\ Grunwaldzki Sq. 24A, 50-363 Wrocław, Poland \\ e-mail: jan.krezel@up.wroc.pl
}

\begin{abstract}
In the experiment carried out in the Experimental Station belonging to the Wrocław University of Environmental and Life Sciences in 2004-2006, we estimated the effect of the type of the nitrogen fertiliser (ammonium nitrate, calcium nitrate, ammonium sulfate, urea and ENTEC 26) applied as preplant $\left(150 \mathrm{~kg} \mathrm{~N} \mathrm{ha}^{-1}\right)$ or split dose (100 $+50 \mathrm{~kg} \mathrm{~N} \mathrm{ha}^{-1}$ ) on the yield and dry matter content, nitrates, vitamin C and $\mathrm{P}, \mathrm{K}, \mathrm{Mg}$, Ca in 'Optiko' Chinese cabbage cultivated during the spring season. The highest total and marketable yield of Chinese cabbage was recorded after the use of urea, which was partly associated with the lowest percentage of diseased heads. Plants fertilised with ammonium sulfate provided the lowest yield. The method of nitrogen application significantly affected the yield and the mean weight of individual heads in the marketable yield, but not the accumulation of nitrates and vitamin $\mathrm{C}$. The lowest accumulation of nitrates was associated with the use of ammonium sulfate and ENTEC 26, whereas the highest with urea. The use of calcium nitrate at a single dose of $150 \mathrm{~kg} \mathrm{~N} \mathrm{ha}^{-1}$ led to the highest accumulation of vitamin $\mathrm{C}$ in Chinese cabbage leaves. The levels of $\mathrm{P}, \mathrm{K}, \mathrm{Mg}$ and $\mathrm{Ca}$ showed only small changes and were not significantly affected by the type of nitrogen fertiliser or the method of its application.
\end{abstract}

Key words: Brassica pekinensis, nitrates, nutrition, vitamin C, yielding

\section{INTRODUCTION}

Chinese cabbage is a vegetable with a short vegetation period and significant sensitivity to the length of the day and low temperatures. It is thus important to choose an appropriate cultivar for the spring period of growing in order to avoid vernalisation and bolting (Kalisz 2005). A high yield of this vegetable crop is also associated with the proper nutrition of plants, especially nitrogen. Inappropriate fertilisation with this nutrient may contribute to the accumulation of increased levels of nitrates in plants and negatively affect the crop size (Rahn 2000, Wang and Li 2004, Wojciechowska and Rożek 2006, Kalisz 2007, Staugaitis at al. 2008). In addition, an excess of nitrogen in the soil might be washed out into the groundwater, leading to contamination of the environment (Rahn 2002). In order to prevent such occurances, it is important to use appropriate doses and forms of nitrogen fertilisers, including slow releasing types or those containing nitrification inhibitors (Rahn 2000, Hähndel and Zerulla 2001).

The objective of the present experiment was the evaluation of the effect of the type of nitrogen fertiliser and the method of its application on the yielding and biological value of Chinese cabbage in spring cultivation.

\section{MATERIAL AND METHODS}

The two-factor field experiment, established using the random block method with four replications, was carried out in 2004-2006 in the Experimental Station 
of the Horticulture Department of the Wrocław University of Environmental and Life Sciences. The type of nitrogen fertiliser (ammonium nitrate $-34 \% \mathrm{~N}$, calcium nitrate $-15 \% \mathrm{~N}$, ammonium sulfate $-21 \% \mathrm{~N}$, urea $-46 \% \mathrm{~N}$ and ENTEC 26 $-26 \% \mathrm{~N}$ ) and the method of its application - as preplant $\left(150 \mathrm{~kg} \mathrm{~N} \mathrm{ha}^{-1}\right)$ or split doses $(100+50 \mathrm{~kg} \mathrm{~N}$ $\left.\mathrm{ha}^{-1}\right)$, with top dressing two weeks after planting out seedlings - were compared. Replication represented ten experimental treatments. The size of the plot prepared for harvest was $5.4 \mathrm{~m}^{2}(1.8 \times 3.0 \mathrm{~m})$.

Phosphorous and potassium fertilisation was carried out according to the results of soil analyses to obtain a final concentration of $60 \mathrm{mg} \mathrm{P}$ and $200 \mathrm{mg} \mathrm{K}$ in $1 \mathrm{dm}^{3}$ of soil.

The 'Optiko' Chinese cabbage cultivar was seeded into multipots (cell diameter $4 \mathrm{~cm}$ ) filled with peat substrate on 16,15 and 20 March of each consecutive year and seedlings were planted into the fields with spacing of $45 \times 30 \mathrm{~cm}$ on 15 April in 2004 and 2005 and 20 April in 2006.

Chinese cabbage was harvested on 6 July, 30 June and 4 July in the subsequent years of the study. The total of the aboveground plant yield, total and marketable yield of heads, unmarketable and diseased heads as well as individual head weight were evaluated. Plant samples were collected during the harvest, three heads of cabbage per plot, for chemical analysis. Dry matter content was evaluated after drying at $105^{\circ} \mathrm{C}$ to constant weight, vitamin $\mathrm{C}$ using the Tillmans' method and according to Polish Standards PN-90/A-75101/11 (Drzazga 1974), phosphorus and magnesium using the spectrophotometric method, potassium and calcium using the flame photometric method and nitrate nitrogen using the potentiometric method. Soluble forms of mineral components of dry mass were analysed in $2 \%$ acetic acid according to the universal method (Nowosielski 1988). All chemical analyses were carried out in duplicates.

The results of the yielding were analysed using the Tukey test with a confidence coefficient of $p=$ 0.05 .

\section{RESULTS AND DISCUSSION}

Data presented in Table 1 indicate that the highest total and marketable yield of heads was obtained after urea fertilisation (respectively 90.84 and $83.53 \mathrm{t} \mathrm{ha}^{-1}$ ). A similar yield level was also observed following calcium nitrate, ammonium nitrate, and ENTEC 26, whereas it was significantly lower after ammonium sulfate use. Such data are in agreement with previous reports by Ducsay and Varga (2003), although Wang and Li (2004) reported no significant effect of the type of nitrogen fertiliser on yielding. These differences may result from variability in the assimilation of nitrogen, which has been shown to depend on the $\mathrm{pH}$ of the soil and its buffer capacity. The split application of nitrogen $(100+50 \mathrm{~kg} \mathrm{~N}$ $\mathrm{ha}^{-1}$ ) reduced total yield by $6.82 \mathrm{tha}^{-1}$ and marketable yield by $6.23 \mathrm{t} \mathrm{ha}^{-1}$ in comparison to the preplant application of the same amount of this nutrient. Generally, the highest total and marketable yield was obtained when urea fertilisation in the amount of $150 \mathrm{~kg} \mathrm{~N} \mathrm{ha}^{-1}$ was used in a preplant dose. The lowest yield of Chinese cabbage was found after split application of ammonium sulfate $(100 \mathrm{~kg} \mathrm{~N}$ $\mathrm{ha}^{-1}$ as preplant and $50 \mathrm{~kg} \mathrm{~N} \mathrm{ha}^{-1}$ two weeks after planting the seedlings).

Table 1. The effect of nitrogen fertilisation on yielding $\left(\mathrm{t} \mathrm{ha}^{-1}\right)$ of Chinese cabbage grown for spring harvest (mean for 2004-2006)

\begin{tabular}{|c|c|c|c|c|c|c|}
\hline \multirow{3}{*}{ Type of fertiliser } & \multicolumn{3}{|c|}{ Total yield of heads } & \multicolumn{3}{|c|}{ Marketable yield } \\
\hline & \multicolumn{2}{|c|}{ Method of application } & \multirow{2}{*}{ Mean } & \multicolumn{2}{|c|}{ Method of application } & \multirow{2}{*}{ Mean } \\
\hline & Preplant & Split & & Preplant & Split & \\
\hline Ammonium nitrate & 93.47 & 84.11 & 88.79 & 85.57 & 74.66 & 80.12 \\
\hline Calcium nitrate & 94.67 & 86.19 & 90.43 & 86.36 & 79.36 & 82.86 \\
\hline Urea & 96.46 & 85.21 & 90.84 & 89.01 & 78.04 & 83.53 \\
\hline Ammonium sulfate & 81.27 & 78.80 & 80.03 & 72.23 & 71.03 & 71.63 \\
\hline ENTEC 26 & 88.63 & 86.09 & 87.36 & 80.51 & 79.44 & 79.98 \\
\hline Mean & 90.90 & 84.08 & & 82.74 & 76.51 & \\
\hline \multicolumn{7}{|l|}{$\mathrm{LSD}_{0.05}$ for: } \\
\hline type of fertiliser & & & 6.27 & & & 6.48 \\
\hline method of application & & & 3.62 & & & 3.00 \\
\hline interaction & & & 8.71 & & & 8.72 \\
\hline
\end{tabular}


The results concerning the structure of the total yield of aboveground plant biomass presented in Figure 1 suggest that the percentage of marketable yield and unmarketable heads did not show any significant differences in response to different methods of nitrogen application. Similarly, the weight of diseased heads and the weight of rosette leaves were also unchanged. With respect to the type of fertiliser, the use of urea was associated with the highest marketable yield when calculated as a percentage of total yield of the aboveground mass (67.66\%). In addition, the use if this $\mathrm{N}$ form was also associated with the lowest percentage of diseased heads and rosette leaves. A relatively high percentage of marketable yield and low amount of diseased heads was also observed in plants fertilised with ENTEC 26. The lowest instance of marketable heads and the highest number of unmarketable heads (below $0.5 \mathrm{~kg}$ ) and rosette leaves were observed in plots with ammonium sulfate application. The use

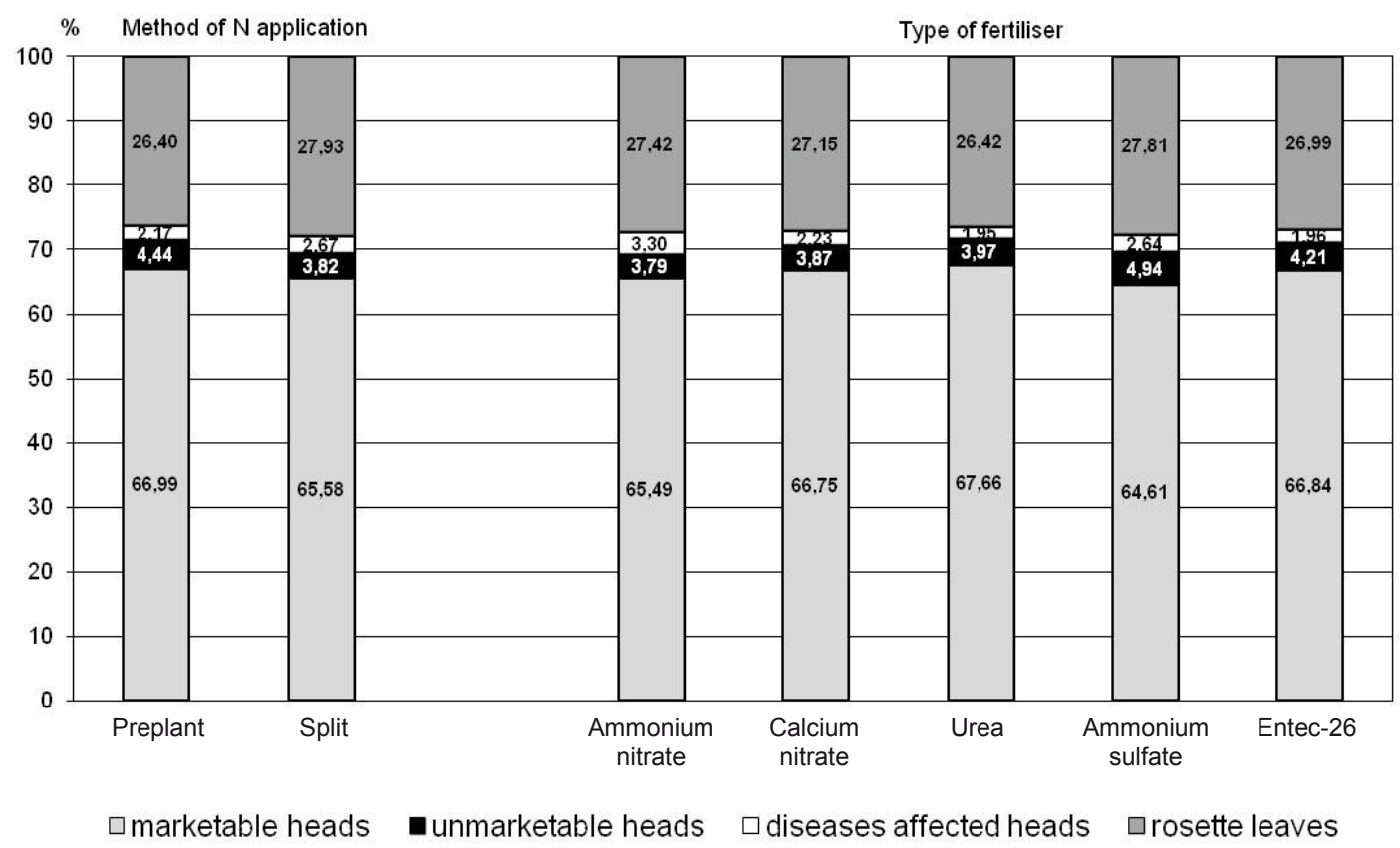

Figure 1. Structure of total yield aboveground biomass of Chinese cabbage in relation to the method of $\mathrm{N}$ application and type of fertiliser in growing for spring harvest (mean for 2004-2006)

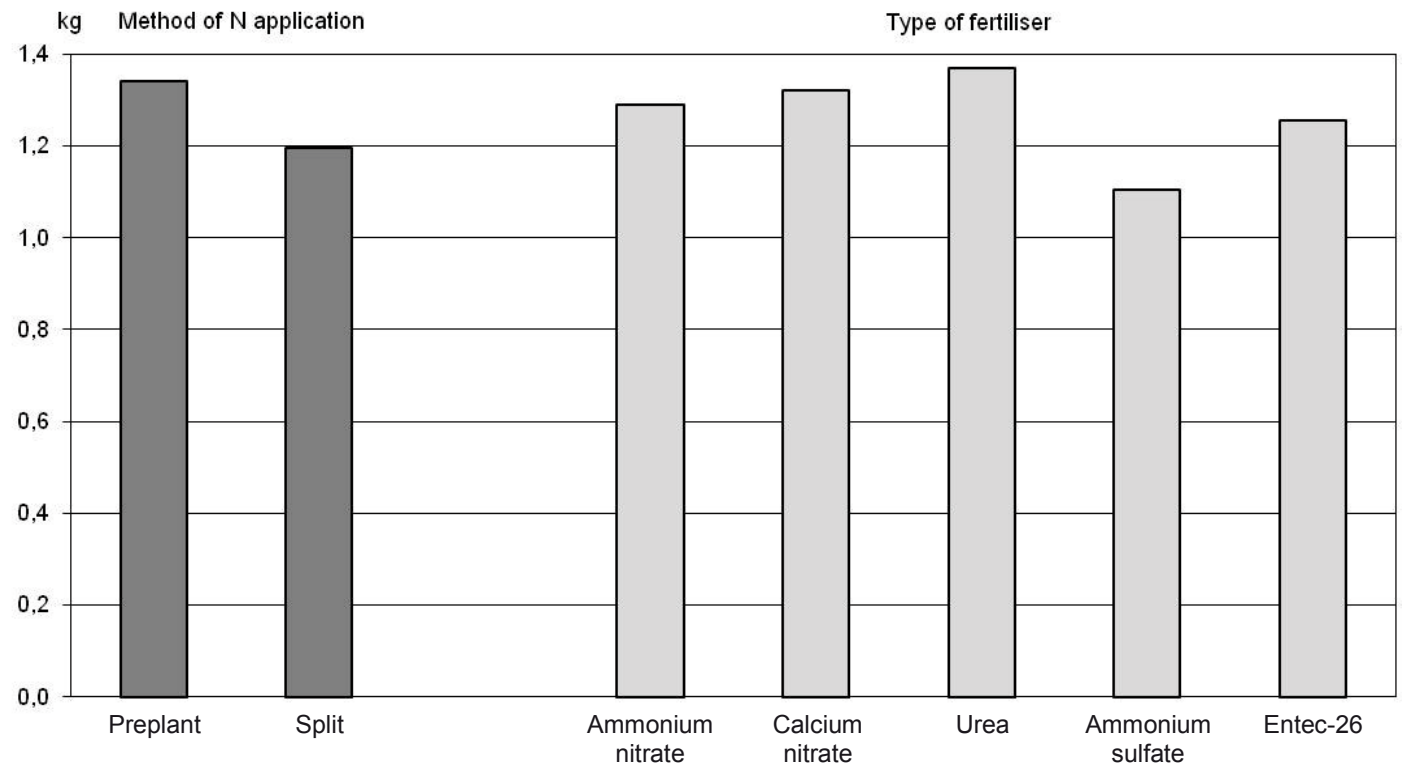

Figure 2. Mean weight of Chinese cabbage head in relation to the method of $\mathrm{N}$ application and type of fertiliser in growing for spring harvest (mean for 2004-2006) 
of ammonium sulfate contributed to a decrease in the health of Chinese cabbage. In consequence, the highest percentage of diseased heads as well as the highest amount of rosette leaves with relatively little weight of unmarketable heads when calculated with respect to the total aboveground mass was found.

Figure 2 summarises the mean weight of marketable heads of Chinese cabbage. Thus, a preplant application of nitrogen fertiliser $(150 \mathrm{~kg}$ $\mathrm{N} \mathrm{ha}{ }^{-1}$ ) led to a higher mean weight of individual heads as compared to a split application $(100+$ $50 \mathrm{~kg} \mathrm{~N} \mathrm{ha}^{-1}$ ). The largest heads were observed on the plots fertilised with urea $(1.37 \mathrm{~kg})$, whereas slightly smaller weight was found after calcium nitrate use. The smallest mean weight of heads was observed after ammonium sulfate application $(1.1 \mathrm{~kg})$.

The strongest tendency to accumulate nitrates was recorded for Chinese cabbage fertilised with urea (236 mg $\mathrm{NO}_{3} \mathrm{~kg}^{-1}$ f.m.), whereas it was significantly less after ammonium sulfate application and ENTEC 26 (Tab. 2). The beneficial effects of fertilisers containing a nitrification inhibitor (DMPP) on decreased nitrate levels was in agreement with previous findings reported by Hähndel and Zerulla (2001). The efficiency of ENTEC 26 was also significantly increased when applied on light or irrigated soils. The method of nitrogen application did not significantly affect nitrate content. This finding confirms our previous studies carried out during spring and autumn terms (Krężel and Kołota 2001, 2008). The effects of different types of fertiliser did not differ with respect to the method of their application, since we observed only tendencies for minor changes which were, however, not significant. Thus the strongest tendency to accumulate nitrates was found in Chinese cabbage fertilised with urea in a preplant single dose of $150 \mathrm{~kg} \mathrm{~N} \mathrm{ha}^{-1}$. The lowest tendency for such accumulation was observed for plants fertilised with ammonium sulfate with split application $\left(100+50 \mathrm{~kg} \mathrm{~N} \mathrm{ha}^{-1}\right)$.

The vitamin $\mathrm{C}$ content in cabbage leaves showed only a tendency for correlation with the type and method of fertiliser supply. Thus, the application of calcium nitrate showed a tendency for higher vitamin $\mathrm{C}$ accumulation as compared to ENTEC 26 , for which such a tendency was the lowest. Considering both of these factors simultaneously, the highest levels of vitamin C $\left(36.09 \mathrm{mg}_{100 \mathrm{~g}^{-1}}\right.$ f.m.) were found in cabbage leaves after a single, preplant application of calcium nitrate at the dose of $150 \mathrm{~kg} \mathrm{~N} \mathrm{ha}^{-1}$. Ducsay and Varga (2003) reported almost double levels of vitamin $\mathrm{C}$ in this vegetable species. This discrepancy may result from lower nitrogen rates used in the latter study $\left(73 \mathrm{~kg} \mathrm{~N} \mathrm{ha}^{-1}\right)$, which is known to lead to higher vitamin $\mathrm{C}$ levels.

None of the investigated factors significantly affected the content of dry matter, phosphorus, potassium, magnesium, and calcium and for this reason these results are not included in the paper.

\section{CONCLUSIONS}

1. During the spring season the highest total and marketable yield of Chinese cabbage associated with the lowest percentage of diseased heads was obtained with urea nutrition. The use of

Table 2. The effect of nitrogen fertilisation on content of nitrates and vitamin $\mathrm{C}$ in Chinese cabbage grown for spring harvest (mean for 2004-2006)

\begin{tabular}{|c|c|c|c|c|c|c|}
\hline \multirow{3}{*}{ Type of fertiliser } & \multicolumn{3}{|c|}{$\begin{array}{c}\text { Nitrates } \\
\left(\mathrm{mg} \mathrm{NO}_{3} \mathrm{~kg}^{-1} \text { f.m.) }\right.\end{array}$} & \multicolumn{3}{|c|}{$\begin{array}{c}\text { Vitamin C } \\
\text { (mg 100 g-1 f.m.) }\end{array}$} \\
\hline & \multicolumn{2}{|c|}{ Method of application } & \multirow{2}{*}{ Mean } & \multicolumn{2}{|c|}{ Method of application } & \multirow{2}{*}{ Mean } \\
\hline & Preplant & Split & & Preplant & Split & \\
\hline Ammonium nitrate & 194 & 223 & 209 & 25.70 & 28.44 & 27.07 \\
\hline Calcium nitrate & 180 & 243 & 212 & 36.09 & 23.92 & 30.01 \\
\hline Urea & 251 & 221 & 236 & 25.63 & 29.21 & 27.42 \\
\hline Ammonium sulfate & 210 & 165 & 188 & 28.13 & 27.97 & 28.05 \\
\hline ENTEC 26 & 206 & 207 & 206 & 24.53 & 29.46 & 27.00 \\
\hline Mean & 208 & 212 & & 28.02 & 27.80 & \\
\hline \multicolumn{7}{|l|}{$\mathrm{LSD}_{0.05}$ for: } \\
\hline type of fertiliser & & & 30 & & & n.s. \\
\hline method of application & & & n.s. & & & n.s. \\
\hline interaction & & & n.s. & & & 11.81 \\
\hline
\end{tabular}


ammonium sulfate led to the lowest yield of heads.

2. Single, preplant application of nitrogen (150 kg N ha ${ }^{-1}$ ) was associated with better yielding, higher mean weight of individual marketable heads as compared to split application $\left(100+50 \mathrm{~kg} \mathrm{~N} \mathrm{ha}^{-1}\right)$. The mode of nitrogen administration did not affect the content of nitrates and vitamin $\mathrm{C}$ in heads.

3. The lowest tendency to accumulate nitrates was associated with the use of ammonium sulfate or ENTEC 26, whereas this tendency was highest for urea.

4. The application of calcium nitrate in a single, preplant dose of $150 \mathrm{~kg} \mathrm{~N}^{-1}$ led to the highest accumulation of vitamin $\mathrm{C}$, whereas its lowest amounts were found in treatment with the use of the same fertiliser, but in a split application (100 $+50 \mathrm{~kg} \mathrm{~N} \mathrm{ha-1}$ ).

\section{REFERENCES}

DrzazGa B., 1974. Analiza techniczna w przetwórstwie owoców i warzyw. Wyd. Szkolne i Pedagogiczne: $277 \mathrm{p}$.

Ducsay L., Varga L., 2003. Cultivation of Brassica pekinensis under different forms of nitrogen nutrition. Hort. Sci. 30(3): 112-115.

Hähndel R., Zerulla W., 2001. Effects of ammoniumstabilized N-fertilizers on yield and quality of vegetables. Acta Hort. 563: 81-86.

Kalisz A., 2005. Przydatność wybranych odmian kapusty pekińskiej (Brassica pekinensis Rupr.) do uprawy wiosennej. Zesz. Nauk. AR we Wrocławiu, Rolnictwo LXXXVII, 515: 223-229.

KALISz A., 2007. Wpływ zróżnicowanych dawek azotu na plonowanie wartość odżywczą kapusty pekińskiej. Roczn. AR w Poznaniu, Ogrodnictwo 41: 511-515.

Krężel J., KoŁota E., 2001. Effect of nitrogen fertilizers on yield and biological value of chinese cabbage grown in spring season. Veg. Crops Res. Bull. 55: 91-95.

Krężel J., Kolota E., 2008. The effect of nitrogen fertilization on yielding and biological value of Chinese cabbage grown from seedlings for autumn harvest. J. Elementol. 13(2): 255-260.

Nowosielski O., 1988. Zasady opracowania zaleceń nawozowych w ogrodnictwie. PWRiL, Warszawa: $310 \mathrm{p}$.
RAHN C.R., 2000. Nitrogen and field production of vegetable crops. Acta Hort. 533: 361-370.

RAHN C.R., 2002. Management strategies to reduce nutrient losses from vegetable crops. Acta Hort. 571: 19-29.

Staugaitis G., VišKelis P., Venskutonis P.R., 2008. Optimization of application of nitrogen fertilizers to increase the yield and improve the quality of Chinese cabbage heads. Acta Agriculturae Scandinavica, Sect. B - Soil Plant Sci. 58(2): 176-181.

WANG Z., Li S., 2004. Effect of nitrogen and phosphorus fertilization on plant growth and nitrate accumulation in vegetables. J. Plant Nutr. 27(3): 539-556.

Wojciechowska R., Rożex S., 2006. Redukcja azotanów w różnych częściach użytkowych warzyw. Folia Hort., Supl. (2): 203-207.

\section{REAKCJA KAPUSTY PEKIŃSKIEJ UPRAWIANEJ W OKRESIE WIOSENNYM NA ZRÓŻNICOWANIE FORMY NAWOŻENIA AZOTOWEGO}

Streszczenie: Celem badań przeprowadzonych w latach 2004-2006 w Stacji Badawczej Uniwersytetu Przyrodniczego we Wrocławiu była ocena wpływu rodzaju nawozu azotowego (saletra amonowa, saletra wapniowa, siarczan amonu, mocznik i Entec 26) i sposobu jego dawkowania (w całości przedwegetacyjnie $150 \mathrm{~kg} \mathrm{~N}^{-1}$ ) lub $\mathrm{w}$ dawce dzielonej $\left(100+50 \mathrm{~kg} \mathrm{~N} \mathrm{ha}^{-1}\right)$ na plonowanie, zawartość azotanów, witaminy $\mathrm{C}$, suchej masy oraz $\mathrm{P}, \mathrm{K}, \mathrm{Mg}, \mathrm{Ca}$ w kapuście pekińskiej odmiany 'Optiko' uprawianej $\mathrm{W}$ okresie wiosennym. Najwyższy plon ogólny i handlowy oraz najmniejszy udział główek chorych kapusty pekińskiej uzyskano przy nawożeniu roślin mocznikiem. Najsłabiej plonowały rośliny nawożone siarczanem amonu. Sposób stosowania azotu istotnie wpływał na poprawę plonowania i masę jednostkową główek handlowych, natomiast nie miał wpływu na kumulację azotanów i witaminy $\mathrm{C}$ w liściach kapusty. Najmniej azotanów kumulowały rośliny nawożone siarczanem amonu i nawozem ENTEC 26, a najwięcej mocznikiem. Zastosowanie saletry wapniowej w dawce $150 \mathrm{~kg} \mathrm{~N}$ ha $^{-1}$ wpłynęło na największą zawartość witaminy $\mathrm{C}$ w liściach kapusty pekińskiej. Poziom suchej masy, $\mathrm{P}, \mathrm{K}, \mathrm{Mg}$ i Ca w roślinie był mało zróżnicowany i nie był w istotny sposób zależny od rodzaju i sposobu dawkowania azotu. 